\title{
Coelodonta antiquitatis in the Pleistocene of Bulgaria (Perissodactyla: Rhinocerotidae)
}

\author{
Zlatozar BOEV
}

National Museum of Natural History, Bulgarian Academy of Sciences, 1, Blvd. Tsar Osvoboditel, BG-1000 Sofia, Bulgaria; boev@nmnhs.com; zlatozarboev@gmail.com

received on 17 December 2020

\begin{abstract}
An analysis of the geographical and altitudinal distribution of remains of the woolly rhinoceros (Coelodonta antiquitatis) in Bulgaria is given. The paper summarizes all scattered data on the distribution of the species gathered in the last 114 years, only a part of them having been published before. Data on nine fossil localities (early-latest Pleistocene) from six provinces of Bulgaria are presented. The fossil record proves the wide species distribution in the riverine foothills of mountains, plains, and lowlands of the country. Its Pleistocene localities were concentrated in the Danubian Plain, although the species was recorded also in the southernmost part of the country. About 90 percent of the localities were situated below $400 \mathrm{~m}$ a. s. 1., although the species' altitudinal distribution reached the maximum of $750 \mathrm{~m} \mathrm{a}$. s. 1 . All findings of the wooly rhinoceros in Bulgaria were made together with those of some species that now inhabit deciduous woodlands or rocky massifs of the temperate zone-Cervus elaphus, Capreolus capreolus, Rupicapra rupicapra, or Capra ibex, as well as extinct Bos primigenius. In Bulgaria, C. antiquitatis showed the same habitat preferences as in the core parts of the species range in Siberia. The Bulgarian localities of findings were both natural habitats and former human dwellings.
\end{abstract}

Key words. Pleistocene megafauna, Rhinoceroses, Quaternary mammals, Balkan fossil fauna, Bulgarian Pleistocene environment

\section{INTRODUCTION}

In the Late Pleistocene, the vast Eurasian tundra-steppe was the homeland of the cold-adapted large mammals, known as "Mammuthus-Coelodonta faunal complex" (BoESKorov 2012) and this zone also covered the territory of Bulgaria. According to MARKova et al. (2011), the Eurasian distribution of the woolly rhinoceros, Coelodonta antiquitatis (Blumenbach, 1799), is broadly proved from 263 localities, 147 of them from Europe. They were dated 50,000 to 9,335 years BP and all of them lie between $45^{\circ}-55^{\circ} \mathrm{N}$. It is interesting that this comprehensive study does not list any data from Bulgaria and the Balkans at all - a region lying on the species range periphery. As well documented, the range of Coelodonta antiquitatis in East Asia reaches even southern China (LuCAs 2001).

The distribution of Coelodonta antiquitatis was not a subject of special research in Bulgaria. BERON et al. (2006) provided data on two cave localities (Malkata Cave and Mirizlivka Cave). BoEv (2017) provided a summary of the published data from six Pleistocene localities of this species in Bulgaria: Temnata dupka Cave, Bačo Kiro Cave, Malkata Cave, 'Unknown site 1' 
in the Loveč Province, 'Unknown site 2' near Pirgovo, and the Mirizlivka Cave. One of these localities, the Bačo Kiro Cave was listed erroneously, as the only finding was in fact identified as Dicerorhinus hemitoechus Falconer, 1860 (KUBIAK 1982). The remnants found in all other localities were listed as Rhinoceros tichorinus Cuvier, 1812 (now considered a synonym of Coelodonta antiquitatis).

The woolly rhinoceros became extinct approximately $14 \mathrm{Ka} \mathrm{BP}$ (LORD et al. 2020). In the westernmost parts of its range (Iberian Peninsula), the species survived until $20 \mathrm{Ka}$ BP (ÁLvAREZ-LAO \& GARCÍA 2011) and the data from Russia indicate the species survival up to $10.2 \mathrm{Ka}$. In Siberia and the Ural Mts., the chronostratigraphic distribution of Coelodonta antiquitatis was confined between 53 and $10 \mathrm{Ka}$ (OrLOVA et al. 2008). However, StUART \& LiSTER (2012) accepted another final date, $14 \mathrm{Ka} \mathrm{BP}$ for the species global extinction.

The territory of Bulgaria also lies on the periphery of its range in the Balkans (GROMOV \& Baranova 1981, Markova et al. 2011, Álvarez-Lao \& García 2011). Thus, any data on its occurrence in the country are valuable for understanding its final history in southern Europe.

\section{MATERIAL AND METHODS}

I tried to gather all scattered data (published and unpublished in the last 114 years) on the former distribution of the woolly rhinoceros throughout the present territory of Bulgaria. For each locality (site) I present as complete data as possible on the age, years and leaders of excavations, and the reference to the original published information (Table 1). The majority of findings came from the excavated archeological localities of prehistoric human cave dwellings.

Thus, many of the findings were published in less accessible (often regional or semi-popular) archeological editions, remaining unknown to the zoological community. All of them represent a valuable source for elucidating former distribution of one of the iconic Pleistocene megamammals in the Balkans.

The chronostratigraphy follows CoHEN et al. (2013): (1) Chibanian (middle Pleistocene, 770,000 129,000 years BP); (2) late Pleistocene (129,000-11,700 years BP) (Table 1).

\section{RESULTS AND DISCUSSION}

A profound literature reference shows that the first published data on Coelodonta antiquitatis in Bulgarian science appeared in 1906 (KovAČEV 1906), i.e. 75 years after its original description. Later Popov (1925) mentioned a Paleolithic finding of "Rhinoceros sp." from the Temnata dupka Cave. Much later Nikolov $(1977,1983)$ confirmed their identification as Rhinoceros tichorinus. Remains of the Middle Paleolithic (Early MIS 5e, 135,000-85,000 years BP) "Rhinocerathidae indet." are reported from the Mišin Kamik Cave (Gurova et al. 2017). Todorova (1984) mentions that Coelodonta antiquitatis was recorded in Dobrudža (NE Bulgaria) without providing a concrete locality and more data.

In the steppes of Eurasia, the woolly rhinoceros, being a cold-adapted megaherbivore (LORD et al. 2020), was never as numerous as other smaller Pleistocene perissodactylians, like the wild horse (tarpan, Equus ferus ferus Boddaert, 1785) or the wild ass (Equus hemionus hydruntinus Regalia, 1907). BoESKOROv (2001: 17) found that in north-eastern Asia "The highest frequency [of Coelodonta antiquitatis ...] was observed on the plateaus and in the mountain river valleys, while in the lowlands and in the long river valleys the rhino remains were rather rare [...]. Numerous remains [...] were [...] also found in mountainous regions". In Bulgaria most of the sites of the species records were located in the northern parts of the country. The only locality in southern Bulgaria (Mečata dupka Cave) is remarkable with its southern and rather remote 


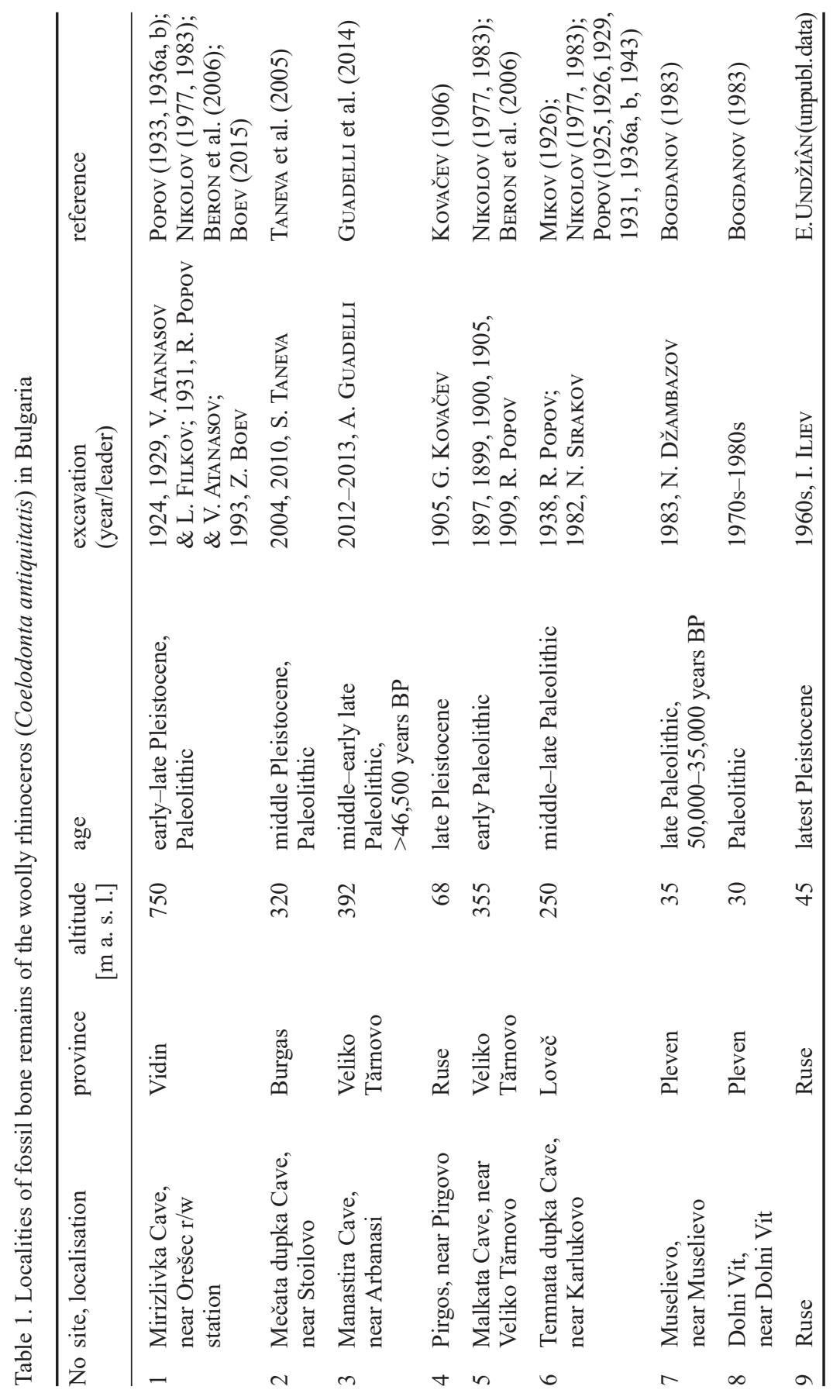




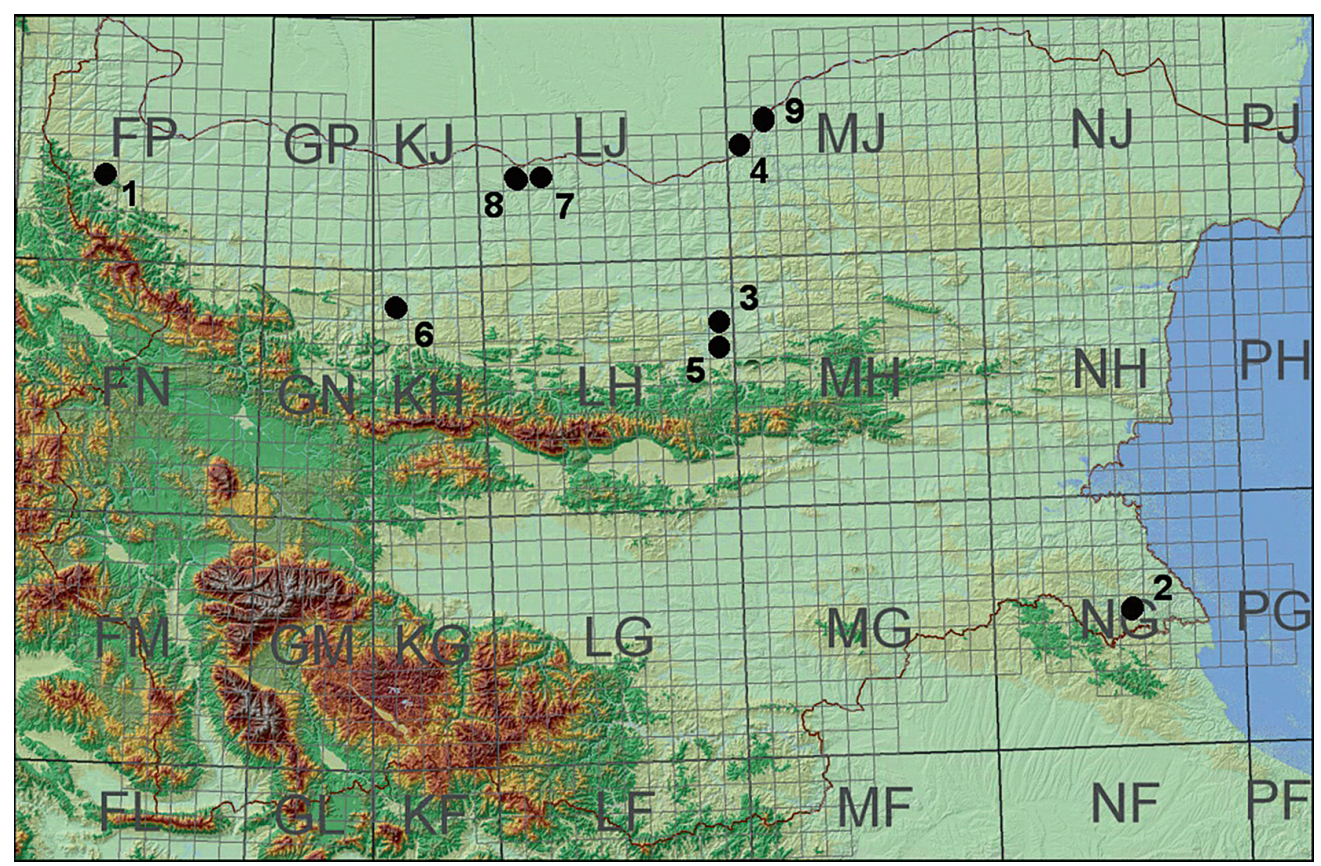

Fig. 1. Distribution of records of Coelodonta antiquitatis in Bulgaria. Numbers correspond to the list of localities in Table 1: Mirizlivka Cave (1), Mečata dupka Cave (2), Manastira Cave (3), Pirgos (4), Malkata Cave (5), Temnata dupka Cave (6), Muselievo (7), Dolni Vit (8), Ruse (9).

position. It is to be noted that all Bulgarian localities of the woolly rhinoceros are located along large rivers or in river valleys: Skomlâ (locality 1), Veleka and Aydere (Haidere) (2), Ântra and Rosica (3 and 5), Danube and Rusenski Lom (4 and 9), Danube and Vit (7 and 8). The altitude distribution is confined between 30 and $750 \mathrm{~m}$ a. s. 1 . About $90 \%$ of localities are located below $400 \mathrm{~m}$ a. s. 1. (30-392 m). Thus, in Bulgaria Coelodonta antiquitatis showed the same habitat preferences as in the centre of the species range in Siberia (ORLOVA et al. 2008).

It is worthy to mention that Coelodonta antiquitatis was a mammal with low migration ability (BOESKOROV 2001). Hence, the localities listed here may reflect authentically the species distribution in the Pleistocene. During the Late Pleistocene, the southern expansion of Coelodonta antiquitatis in the Balkans reached the south-eastern corner of the Peninsula (Strandža Mts., ca. $42^{\circ} \mathrm{N}$; Fig. 1). The species was recorded also in the neighbouring Serbia (MARKović 1998). This region approaches the latitudes of localities from other regions of Eurasia, although the southernmost margin of the species occurrence is located at $33^{\circ} \mathrm{N}$ in southern China (STUART \& LISTER 2012).

The record shows that Coelodonta antiquitatis inhabited largest plains and lowlands in Bulgaria. Eight of the total of nine localities are located in the Danubian Plain, but one in the foothills of the Strandža Mts. which border the third largest plain of Bulgaria - the Burgas Lowland (Fig. 1). 
The sites of Muselievo and Manastira are among the oldest European localities of the wooly rhinoceros, being dated approximately to 50-45 Ka.

In the Mirizlivka Cave, the findings of the woolly rhinoceros were made together with those of some species that inhabit the temperate zone of Eurasia-Cervus elaphus Linnaeus, 1758, Capra ibex Linnaeus, 1758, and Bos primigenius (Bojanus, 1827) (BoEv 2015). In the area of the Temnata dupka Cave, Coelodonta antiquitatis coexisted with Cervus elaphus, Capreolus capreolus (Linnaeus, 1758), Rupicapra rupicapra (Linnaeus, 1758), Capra ibex, and Bos primigenius (GUADELLI \& DELPECH 2000). A similar composition of the associated fauna was found at other sites - the coexisting species were Cervus elaphus and Rupicapra rupicapra in Muselievo (Bogdanov 1983), Bos primigenius at the Malkata Cave (Popov 1911), and Bos sp. at the Manastira Cave (GuADELli et al. 2014). These records confirm that not only in the southwestern periphery of the range of Coelodonta antiquitatis in the Iberian Peninsula (Álvarez-Lao \& García 2011), but also in the Balkans, there existed an association of the woolly rhinoceros with other taxa of the "temperate and forested environments ..., showing a mixture of temperate and cold elements which does not reflect the typical faunal composition of the Eurasian tundra-steppe" (ÁLVAREZ-LAO \& GARCíA 2011: 2016). We have to remind that the same faunal complexes occurred even at the southern peripheries of the range of this species in central Siberia (ForONOVA 1982) and in southern Italy (GATTA et al. 2019).

It could be summarised that in the period of the last 114 years only nine localities of Coelodonta antiquitatis were documented in Bulgaria. All these findings were made occasionally, and no special paleontological research was undertaken.

The Bulgarian localities of the wooly rhinoceros represent both natural habitats and former human dwellings (caves). The data on Neolithic paintings of Coelodonta antiquitatis in some caves of Europe (CARROLL 1988) seem intriguing indeed. We already mentioned that the species became extinct no later than $14 \mathrm{Ka}$, i.e., before the early Neolithic. As Romer (1946: 440) states, the wooly rhinoceros "was a favorite subject for Old Stone Age artists" and not for New Stone Age (Neolithic), as the species did not existed until the Neolithic. Anyway, no images of the woolly rhinoceros are known from Bulgaria. All localities presented here revealed a very scant fossil material, but certainly still sufficient to outline the former distribution of the species in the country.

\section{РЕЗЮМЕ}

Косматият носорог (Coelodonta antiquitatis) в плейстоцена на България (Perissodactyla: Rhinocerothidae). Представен е анализ на географското и надморското разпространение на останките от космати носорози в България. Статията обобщава всички разпръснати данни от последните 114 години за разпространението на косматия носорог, част от които непубликувани. Представени са данни за 9 находища (ранен-най-късен плейстоцен) от 6 от 28-те области в страната. Фосилните данни от България доказват широкото разпространение на вида в крайречните подножия на планините, в равнините и низините. Плейстоценските му находища са съсредоточени в Дунавската равнина, въпреки че видът е регистриран и в най-южната част на страната. Около 90 процента от находищата са разположени под $400 \mathrm{~m}$ надморска височина. Неговото разпространение достига до $750 \mathrm{~m}$ н. в. Всички находки са открити заедно с тези на някои видове, които днес обитават широколистни гори или скални масиви в умерения пояс - благороден елен, сърна, дива коза или алпийски козирог, както и изчезналия тур. По този начин в България C. antiquitatis показва същите предпочитания към местообитанията, каквито е имал в централните части на ареала си в Сибир. Българските находища са както природни (неантропогенни), така и бивши човешки жилища. 


\section{REFERENCES}

Álvarez-Lao D. J. \& García N., 2011: Southern dispersal and Palaeoecological implications of woolly rhinoceros (Coelodonta antiquitatis): review of the Iberian occurrences. Quaternary Science Reviews, 30: 2002-2017.

Beron P., Daaliev T. \& Jalov A., 2006: Caves and Speleology in Bulgaria. Pensoft Publishers, Sofia, $507 \mathrm{pp}$.

Boeskorov G., 2001: Woolly rhino (Coelodonta antiquitatis) distribution in Northeast Asia. Deinsea, 8: $15-20$.

BoESKOROv G., 2012: Some specific morphological and ecological features of the fossil woolly rhinoceros (Coelodonta antiquitatis Blumenbach 1799). Biology Bulletin, 39: 692-707.

Boev Z., 2015: Fossil and subfossil remains of birds and mammals from the Mirizlivka cave (Vidin Region - NW Bulgaria). ZooNotes, 75: 1-3.

Boev Z., 2017: Fossil records of rhinoceroses (Rhinocerotoidea Gray, 1821), chalicotheres (Chalicotherioidea Gill, 1872) and brontotheres (Brontotherioidea (Marsh, 1873) (Peryssodactyla Owen, 1848 - Mammalia Linnaeus, 1758) in Bulgaria. Bulletin of the Natural History Museum - Plovdiv, 2: 1-7.

Bogdanov G., 1983: Naj-bogatoto paleolitno nahodiŝe v Evropa [The richest Paleolithic site in Europe]. Priroda i Znanie, 9: 14 -15 (in Bulgarian).

Carroll R., 1988: Vertebrate Paleontology and Evolution. W. H. Freeman and Company, New York, $698 \mathrm{pp}$.

Cohen K. M., Finney S. C., Gibbard P. L. \& FAn J.-X., 2013: The ICS International Chronostratigraphic Chart. Episodes, 36: 199-204.

ForONOvA I., 1982: Novie nahodki mlekopitaûŝih v plejstocenovyh otloženiâh Kuzneckoj kotlovini [New findings of mammals in the Pleistocene deposits of the Kuznetsk Basin]. Trudy Zoologičeskogo Instituta AN SSSR, 3: 50-56.

Gatta M., Kotsakis T., Pandolfi L., Petronio C., Salari L., Achino K. F., Silvestri L. \& Rolfo M. F., 2019: The late Pleistocene faunal assemblage from Cava Muracci (Latium, Italy): Palaeoenvironmental implications for coastal central Italy during MIS 3. Comptes Rendus Palevol, 18: 51-71.

Gromov I. \& Baranova G. (eds.), 1981: Katalog mlekopitâ̂sih SSSR (pliocen-sovremennost') [Catalogue of Mammals of the Soviet Union (Pliocene-Recent)]. Nauka, Leningrad, 456 pp (in Russian).

Guadelli J.-L. \& Delpech F., 2000: Les Grandes Mammifères du début du paléolithique supérieur à Temnata. Pp.: 53-158. In: Ginter B., Kozlowski J. K. Guadelli J.-L. \& LaVille H. (eds): Temnata Cave. Excavation in Karlukovo Karst Area, Bulgaria. 2.1. Jagellonian University, Cracow, 418 pp.

Guadelli A., BoÂdžIev K., Guadelli J.-L., Crevrcoeur I., KarastoÂnova N., 2014: Peŝera Manastira, Velikotărnovsko [Manastira Cave, Veliko Tărnovo Province]. Pp.: 29-31. In: GuRovA M. (ed.): Arheologičeski otkritiâ i razkopki prez 2013 g. [Archeological Discoveries and Excavations in 2013]. TDG Print, Sofiâ, 683 pp (in Bulgarian).

Gurova M., Ivanova S., Spassov N., Hristova L., Popov V., Marinova E. \& Bohme M., 2017: Proučvane na peŝerata Mišin Kamik - sezon 4 [Excavations at the Mišin Kamik Cave: 2016 season]. Pp.: 48-50. In: Vagalinski L. (ed.): Arheologičeski otkritiâ i razkopki prez $2016 \mathrm{~g}$. [Archeological Discoveries and Excavations in 2016]. Bulged Ltd., Sofiâ, 796 pp (in Bulgarian, with a summary in English).

Kubiak H., 1982: Rhinoceratidae. Pp.: 55-56. In: Kozlowski J. K. \& Ginter B. (ed.): Excavation in Bacho Kiro Cave (Bulgaria). Final Report. Państwowe Wydawnictwo Naukowe, Warszawa, 172 pp.

KovAČEv G., 1906: Namereni ostanki ot parvobiten nosorog [The remains of a primitive rhinoceros discovered]. Priroda, 8-9: 68 (in Bulgarian).

Lord E., Dussex N., Kierczak M., Díez-Del-Molino D., Ryder O. A., Stanton D. W. G., Gilbert M. T. P., Sanchez-Barreiro F., Zhang G., Sinding M.-H. S., Lorenzen E. D., Willerslev E., Protopopov A., Shidloviskiy F., Fedorov S., Bocherens H., Nathan S. K. S. S., Goossens B., van der Plicht J., Chan Y. L., Prost S., Potapova O., Kirillova I., Lister A. M., Heintzman P. D., Kapp J. D., Shapiro B., Vartanyan S., Götherström A. \& Dalen L., 2020: Pre-extinction demographic stability and genomic signatures of adaptation in the woolly rhinoceros. Current Biology, 30: 3871-3879. 
LuCAS S., 2001: Chinese Fossil Vertebrates. Columbia University Press, New York, 375 pp.

Markova A. K., Puzačenko A. Û., Kol'fshoten T., van der Pliht I. \& Ponomarev D. V., 2011: Novejšie dannye o dinamike arealov mamonta i šerstistogo nosoroga v Evrope vo vtoroj polovine pozdnego plejstocena - golocena [Recent data on the dynamics of mammoth and wooly rhinoceros ranges in Europe in the second half of the late Pleistocene - Holocene]. Izvestiâ Rossijskoj Akademii Nauk, Seriâ Geografičeskâ̂, 4: 54-65 (in Russian).

MARKović Z., 1998: Woolly rhinoceros Coelodonta antiquitatis (Blumenbach, 1803) from Pleistocene of Serbia. Bulletin of the Natural History Museum, Belgrade, 47-50: 217-237.

Mıкov V., 1926: Peŝeri i propasti meždu Iskar i Vit [Caves and chasms between Iskar and Vit rivers]. Estestvoznanie i Geografiâ, 7-8: 236-249 (in Bulgarian).

NiKolov I., 1977: Pregled na peŝernata fosilna bozajna fauna v Bălgariâ i badeŝite problemi [Review of the cave fossil fauna of Bulgaria and future problems]. Pp.: 98-101. In: Dinev L., Panajotov T. \& Popov N. (eds.): Speleologiâ. Dokladi izneseni na speleoložkata konferencia, sastoâla se na 10. 12. 1976 g., organizirana ot Bălgarskata akademiâ na naukite i Bălgarskiâ turističeski săuz - Bălgarska federaciâ po peŝerno delo [Spelelogy. Proceedings of the Speleological Conference, Held on 10 December 1976, Organised by the Bulgarian Academy of Science, and Bulgarian Touristic Union-Bulgarian Speleological Federation]. Bălgarskata Akademiâ na Naukite, Sofiâ, 158 pp (in Bulgarian).

NiKoLOV I., 1983: Nâkoj beležki varhu peŝernata fosilna bozajna fauna v Bălgariâ [Some notes on the cave fossil mammalian fauna in Bulgaria]. Pp.: 215-218. In: DiNEv L. (ed.): Četvarta evropejska regionalna konferenciâ po speleologiâ, septemvri, 1980 [Fourth European Regional Conference on Speleology, September 1980]. Bălgarska federaciâ po peŝerno delo, Sofiâ, 403 pp (in Bulgarian).

Orlova L., Vasil'ev S., KuZ'Min Y. \& Kosintsev P., 2008: New data on the time and place of extinction of the woolly rhinoceros Coelodonta antiquitatis Blumenbach, 1799. Doklady Biological Sciences, 423: 403-405.

Popov R., 1911: Malkata peŝera v Tarnovskiâ dervent [Malkata Cave in the Tarnovo Dervent]. Estestvoznanie, 3: 148-166 (in Bulgarian).

PoPOv R., 1925: Novi nahodki ot predistoričeskiâ čovek v Bălgariâ [New findings of the prehistoric man in Bulgaria]. Priroda, 3-4: 33-34 (in Bulgarian).

Popov R., 1926: Peŝerata Temnata dupka pri Karlukovo [Temnata dupka Cave near Karlukovo]. Bălgarski Turist, 1: 5-8 (in Bulgarian).

Popov R., 1929: Doistoričeska Bălgariâ [Prehistorical Bulgaria]. Hristo Danov, Sofiâ, 76 pp (in Bulgarian).

Popov R., 1931: Temnata dupka - novo nahodiŝe ot paleolita v Bălgariâ [Temnata Dupka - a new locality of the Paleolithic in Bulgaria]. Izdaniâ na Narodniâ Arheologičeski Muzej v Sofiâ, 24: 1-148 (in Bulgarian).

Popov R., 1933: Peŝerata Mirizlivka. Prinos kam diluvialnata fauna i kulturata na diluvialniâ čovek [The Mirizlivka Cave. A contribution to the diluvial fauna and the culture of the diluvial man]. Izdaniâ na Narodniâ Arheologičeski Muzej, 26: 1-74 (in Bulgarian).

Popov R., 1936a: Fosilni i subfosilni životinski ostanki v izsledvanite do sega peŝeri na Bălgariâ [Fossil and subfossil animal remains in the caves of Bulgaria studied so far]. Izvestiâ na Bălgarskoto Peŝerno Družestvo, 1: 1-12 (in Bulgarian).

Popov R., 1936b: Fosilni ostanki ot koziroga (Capra aegagrus)] namereni v Bălgariâ [Fossil remains of the wild goat (Capra aegagrus) found in Bulgaria]. Priroda i Nauka, 8-9: 128-129 (in Bulgarian).

Popov R., 1943: Kratko rakovodstvo po praistoriâ. Čast I. Paleolit (Stara kamenna epoha) s ogled na paleolita v Bălgariâ [A Short Handbook on Prehistory. Part I. Paleolithic (Old Stone Age) in order of the Paleolithic in Bulgaria]. Universitetsko izdatelstvo, Sofiâ, 156 pp (in Bulgarian).

StUART A. \& LisTER A., 2012: Extinction chronology of the woolly rhinoceros Coelodonta antiquitatis in the context of late Quaternary megafaunal extinctions in northern Eurasia. Quaternary Science Reviews, 51: $1-17$.

Taneva S., KovaČEva N., Dimitrova I. \& Spasov R., 2005: Terenni izdirvaniâ na paleolitni obekti v rajona na Strandža [Field investigations of the Paleolithic objects in the region of the Strandža Mts.]. P.: 17. 
In: Torbatov S. (ed.): Arheologičeski otkritiâ i razkopki prez 2004 g. [Archeological Discoveries and Excavations in 2004]. [Publisher not indicated], Sofiâ, 333 pp (in Bulgarian).

Todorova H., 1984: Dobrudža prez epohata na paleolita i mezolita [The Dobrudža Region in the epoch of Paleolithic and Mesolithic]. Pp.: 27-71. In: Fol A. \& Dimitrov S. (eds.): Istoriâ na Dobrudža. Tom 1 [History of Dobrudža Region. Volume 1]. Bălgarska Akademiâ na Naukite, Sofiâ, 196 pp (in Bulgarian). 